\title{
Non-financial information in IBEX 35: Comparison of voluntary vs compulsory elaboration and assurance
}

\author{
Esther Ortiz iD, Iryna Didychuk (D) \\ University of Murcia (Spain) \\ esther@um.es,didychuk.iryna@gmail.com
}

Received March, 2021

Accepted July, 2021

\section{Abstract}

Purpose: Large companies are used to elaborating and verifying non-financial information voluntarily. In Spain, it is compulsorily required after Law 11/2018. These new compulsory requirements have led us to study how the previous voluntary practices have been modified and if there is a connection between the auditing and providing assurance company.

Design/methodology: The studied sample compiles companies listed on IBEX 35 in 2018 to analyze the first year of application of Law 11/2018, 2018, and the previous one, the year 2017, when this information was voluntarily disclosed. We have created a database with features of non-financial information to carry out a descriptive analysis segmenting the sample by year, cross tables and chi-square tests.

Findings: Big Fours are the companies that provide assurance of non-financial information as well as audit the financial information of listed companies. Law 11/2018 has not implied important changes for the IBEX 35 companies because what was compulsorily required at first was previously voluntarily done, i.e. the majority of companies have already applied GRI (Global Reporting Initiative) standards when it was voluntary and also when compulsory and they keep including non-financial information in the management report. It has been also checked that auditing and providing assurance firms are specialized by sectors.

Originality/value: Currently there is an intense discussion about the future of non-financial information regulation in Europe. The expected changes will affect the Spanish regulation as a Member State. It is a need to contextualize the starting point.

Keywords: Non-Financial Information, Assurance, Auditing, GRI, Law 11/2018, IBEX 35

Jel Codes: M40, M41, M42

\section{To cite this article:}

Ortiz, E., \& Didychuk, I. (2021). Non-financial information in IBEX 35: Comparison of voluntary vs compulsory elaboration and assurance. Intangible Capital, 17(2), 91-107. https://doi.org/10.3926/ic.1758 


\section{Introduction}

Currently, the environment is characterized by globalization and free trade of information, and in this context, there is a wider range of people interested in having access this information than before. These people interested in accessing information, who are called stakeholders, have increased the information requirements from financial information, that is traditionally published by companies, to additional information about other aspects of the company, such as environmental aspects, social matters, employees' questions, human rights, or fight against corruption or bribery, among others. This is called non-financial information or also sustainability information and it is published in a specific report (Crowther \& Ortiz, 2013). Standards of non-financial information by Global Reporting Initiative (GRI) (GRI is an international private organization) are the ones voluntarily used around the world to elaborate these non-financial information statements or sustainability reports and sometimes are used in addition to other complementary standards or frameworks. These reports are usually verified by auditing companies, although this verification of non-financial information that is called assurance, can be provided by any independent expert on the subject, even the same auditor of the financial information. Prior to the Law 11/2018, these non-financial reports were always verified by GRI voluntarily.

European Directive of 2014 establishes that large European companies must publish non-financial information, and also that it is advised its assurance but not compulsorily. The transposition of this Directive in Spain finished when Law 11/2018 of December 2018 was published, which was required from 1st of January 2018 and implies publishing non-financial information in the management report, or at least, it must be stated in the management report where this non-financial information is published, and its compulsory assurance by an independent expert. For all these reasons, we propose to analyze how these new requirements of non-financial information have affected the previous voluntary practices on disclosure and assurance in Spain. We have focused our research on how changes caused by compulsory requirements influenced the role of auditors and assurance providers. The auditor only has to check if this information is included or mentioned in the management report. The opinion about non-financial information is issued by the assurance provider, who can also be the auditor of the financial information.

The subject studied in this paper is being currently discussed, not only because obligatory elaboration of nonfinancial information is very recent in Spain, but also because we are immersed in an intense standardization and harmonization process in this field in Europe. One of the goals included in the European strategy of the Green Deal is the review of the Non-financial information Directive, and in parallel, the European Commission mandated the European Financial Reporting Advisory Group (EFRAG) to report on possible European NonFinancial Reporting Standards. To succeed in this mandate the EFRAG created a group of experts ad-hoc: the Project Task. Force on Non-Financial Reporting Standards (PTF-NFRS), that published its final report with proposals to a possible European sustainability standards setter on 8th March 2021 (EFRAG, 2021a). This final report includes all the proposals concerning how homogeneous European standards should be on this field, bearing in mind the influence of the sector and the size of the company, the need to externally and independently verify sustainability information, or what the location of this non-financial information should be, always being aligned with other existing frameworks around the world (EFRAG, 2021a). EFRAG report on its future structure and governance was also published at the same date due to the importance of non-financial standardization in Europe. There would be two different boards but intimately linked and coordinated: one for the financial information, and another one for the non-financial one. With this structure, it would be possible to comply with the new requirements on future European non-financial standards by the EFRAG itself (EFRAG, 2021b). And, finally, at the end of April 2021, the European Commission has published a proposal of Directive for sustainability reporting, finalizing in this way the three steps initially given by the European Union, which have been useful to accelerate the process of harmonization and standardization of the non-financial information internationally (IFRS, 2021).

The objective of this paper is to analyze the impact of Law 11/2018 during its first year of application in Spain over the 35 companies listed on the main Spanish index. Data from 2017 and 2018 has been studied in order to compare the last year of voluntary elaboration and assurance of non-financial information in Spain, and the first year of compulsory information. Firstly, we have compared the core features of the non-financial information 
dated the year before the publishing of this Law (2017), when it was still voluntary, and the same features in the first year of compulsory requirements (2018). We have also added information about the traditional auditing of financial statements because the auditing company in the large companies analyzed in the sample is the same that the one in charge of the assurance of non-financial information. The final stage of the analysis focuses on the relationship between the auditing company and assurance company; if both are the same during the two analyzed years as well as the assurance changes from voluntary to compulsory. If there could be a relationship with sector and auditing/assurance company. The structure of this paper is the following: Firstly, we have stated the main background on the field; then we have described the sample and used methodology, and finally, we have given details of the obtained results to finish drawing the main conclusions reached.

\section{Background}

Historically the company reporting was oriented to accountability, to satisfy the need for information for shareholders. Currently, due to easier access to information, the importance of capital markets, globalization, and mainly in the scope of international companies, the groups of people interested in company reporting are broader than before and the concept of stakeholders is used (Laudal, 2011). Traditionally, large international listed companies have disclosed non-financial information. This disclosure has allowed them to count on a communication tool to improve their corporate image and to send a message to the market, increasing their credibility to be able to control public opinion (Brammer \& Pavelin, 2006). Non-financial information is also useful to increase investors' confidence in the company and to be aware of the risks to society, because it offers data about the company's performance (Hernández, 2017). Investors value positively the publishing of sustainability reportings (Berthelot, Coulmont \& Serret, 2012) and it allows to improve the market value (Brammer \& Pavelin, 2006) or to get bigger direct benefits as it is established in the theory of "win-win proposition" (Levy, Szejnwald \& De Jong, 2010).

Publishing of non-financial information has taken to the external assurance of it as a traditional voluntary trend. This assurance is done by an independent expert on verification. The auditor is in charge of checking if nonfinancial information is included, or mentioned where it is included, in the management report, because in Spain according to Law 11/2018 non-financial information can be published in a separate report. However, the independent expert in charge of assurance will be the one who verifies if the content of non-financial information follows the standards used to elaborate it. It must be pointed out that to provide the assurance is not incompatible with auditing of financial information and that assurance is costly and so not all companies pay for it if it is voluntary, and mainly when speaking about not so large companies. Even large companies have made an effort to improve their non-financial reporting because the compulsory assurance means complying with nonfinancial standards and so passing an independent external valuation which has public implications if the final report of the assurance providers includes some kind of assurance exceptions (World Business Council For Sustainable Development [wbcsd], 2016). 60\% of the assurance of large companies operating in all sectors in Spain, Italy, France, United Kingdom, and Germany in 2016, were only related to specific sections of the nonfinancial report, which decreases the quality of the assurance because non-financial information is only partially checked due to the fact that is voluntary (Ortiz \& Fuster, 2019). In the latest study published by KPMG (2017), as regards corporative reporting, more than half of Spanish companies have got independent assurance, over the analyzed average in more than 10 points (KPMG, 2017).

According to those studies focused on companies listed on Spanish Ibex 35, the conclusion is that there is no homogeneity in the presentation of non-financial information, regardless of the use of the same standards during time as GRI standards (González \& Ortiz, 2017; Marín \& Ortiz, 2018; Ortiz \& Marín, 2014, 2016; Rubio \& Ortiz, 2019), and the use of other complementary international standards such as Global Compact or ISO 26000 (Albareda, 2013). Concerning external assurance, it is concluded that it is voluntary and mainly checked by large auditing companies (Ortiz \& Marín, 2014).

Throughout time the most common practice was to split financial and non-financial information, and now there is a trend to elaborate integrated reports. This trend is also popular in Spain (Ortiz \& Fuster, 2019). Integrated reporting implies doing only one report following the framework by the International Integrated Reporting 
Council (IIRC), in which is included the multi capital vision of the company to offer a general overview. It is a way to show transparently to the stakeholders about future strategies and to be able to compare information from different companies (Ortiz \& Fuster, 2019). However, not all companies publish the same integrated information because it is influenced by their size or their leverage (Kilic \& Kuzey, 2018). There is still a long way to go in order to comply with integrated reporting since these reports do not comply with all the established framework (Ortiz, Marín \& Sánchez, 2020). Spanish companies are used to using this format, being the third in the world ranking of integrated reporting according to IIRC framework (KPMG, 2017).

Disclosure of non-financial information and its assurance have been traditionally voluntary. In April 2013 the European Commission and the Parlament proposed the European Directive on Non-financial information issued in 2014. This standardization establishes the requirements to elaborate and assurance non-financial information of European groups of companies and public interest entities (Ortiz, Marín \& Santos, 2019). As it is a Directive, its transposition in Spain was finished with the Law 11/2018 (Goicoechea, Gómez-Bezares \& Goitia-Berriozabal, 2020). In Spain, the Directive scope is extended including not only consolidated statements but also individual statements of large companies, together with public interest entities (Law 11/2018, Preámbulo II). As it has just been explained, these companies included in the scope used to voluntary elaborate and provide assurance of non-financial information. Prior to conclusions, this means that this Law does not suppose significant changes in the practices.

Law 11/2018 establishes that this report must offer a description of the business model of the company (or the group), a description of the policies and their results, and the main risks related to the company. It also lists what topics must be included in this report: environmental aspects, social matters, employees' questions, human rights, or fight against corruption and bribery, and the latest information about the society, such as suppliers, consumers, subcontracts, and fiscal data" (Law 11/2018, First article).

The publishing of this Law means an important change in Spain and for this reason, the objective of this paper is to analyze its first-year application to the main 35 companies listed in Spain to compare with the last voluntary year of elaboration and assurance of non-financial information. Firstly, we compare the last 2 years, analyzing the core features of non-financial information to be able to check the following research question:

1. Has Law 11/2018, which requires compulsory elaboration and assurance of non-financial in-formation, implied important changes concerning what was done in the previous year of its first application?

Secondly, taking for granted that auditing of the financial information in the large listed companies is done by the large auditing companies that are the same in charge of the assurance of non-financial information, we propose the following research questions:

1. Is there a relationship between the auditing company of financial information and the company that provides assurance of non-financial information?

2. Does the auditing company of the financial information change when assurance is compulsorily required instead of voluntarily?

3. Does the company that provides assurance change when assurance is compulsorily required instead of voluntarily?

4. Is there a relationship between the auditing company of financial information and the sector of the audited company?

5. Is there a relationship between the company that provides assurance of non-financial information and the sector of the assured company? 


\section{Methodology and sample}

\subsection{Methodology}

In this study, we have analyzed companies listed on Spanish Ibex 35. These are large companies and due to their size, they have to publish their non-financial information on their website and also to assurance it. As a result, it allows us to easily access this information. To compile all the information, companies listed in 2018 were chosen. Even if the listed companies on 2018 were not the same in 2017, there was not significant difference.

\begin{tabular}{|c|c|}
\hline Variable & Category \\
\hline \multicolumn{2}{|c|}{ Variables related to non-financial information } \\
\hline Standards used in the non-financial information & $\begin{array}{l}\text { GRI } \\
\text { Other standards }\end{array}$ \\
\hline Scope of the GRI standards used & $\begin{array}{l}\text { Core } \\
\text { Exhaustive } \\
\text { Non-GRI }\end{array}$ \\
\hline $\begin{array}{l}\text { Location of non-financial information (where non-financial } \\
\text { information is located) }\end{array}$ & $\begin{array}{l}\text { Apart from annual accounts (AACC) } \\
\text { Included in the management report (MR) } \\
\text { Annex of annual accounts } \\
\text { Annex of MR }\end{array}$ \\
\hline $\begin{array}{l}\text { Disclosure of non-financial information (where non-financial } \\
\text { information is included when it is not in the Shareholders link } \\
\text { of the company website) }\end{array}$ & $\begin{array}{l}\text { Annual accounts } \\
\text { Management report } \\
\text { Annual report } \\
\text { Corporate Social Responsibility (CSR) } \\
\text { Other }\end{array}$ \\
\hline $\begin{array}{l}\text { Disclosure of non-financial information in a specific place out } \\
\text { of Shareholders link of the company website }\end{array}$ & $\begin{array}{l}\text { There is no specific place } \\
\text { Sustainability } \\
\text { Corporate Social Responsibility }\end{array}$ \\
\hline $\begin{array}{l}\text { Name of the report that includes the non-financial information } \\
\text { when it is not included in the annual accounts }\end{array}$ & $\begin{array}{l}\text { Corporate Social Responsibility report } \\
\text { Non-financial information } \\
\text { Sustainability report }\end{array}$ \\
\hline \multicolumn{2}{|c|}{ Variables related to auditing and assurance } \\
\hline Auditing company for financial information & $\begin{array}{l}\text { Deloitte } \\
\text { PWC } \\
\text { EY } \\
\text { KPMG }\end{array}$ \\
\hline $\begin{array}{l}\text { The company that provides assurance of non-financial } \\
\text { information }\end{array}$ & $\begin{array}{l}\text { There is no assurance } \\
\text { Deloitte } \\
\text { PWC } \\
\text { EY } \\
\text { KPMG } \\
\text { Other company }\end{array}$ \\
\hline Opinion in the auditing report & Positive \\
\hline Variable & Category \\
\hline Scope of the non-financial information & $\begin{array}{l}\text { Exhaustive } \\
\text { Limited }\end{array}$ \\
\hline \multicolumn{2}{|c|}{ Other analyzed variables } \\
\hline Year & $\begin{array}{l}2017 \\
2018\end{array}$ \\
\hline Sector where the company operates & $\begin{array}{l}\text { Banking } \\
\text { Energy } \\
\text { Construction } \\
\text { Services } \\
\text { Industry }\end{array}$ \\
\hline
\end{tabular}

Table 1. Variables analyzed and their categories 
With this chosen sample the next step was to compile all the information to elaborate a database for the two years above mentioned. All the variables included are focused on three features of the information: variables referred to non-financial information, features of auditing and assurance, and other variables, specifically year and sector of the company. All the studied variables are obtained after a thorough analysis of the characteristics of non-financial information and auditing reports on the website of the companies included in the sample (information is codified according to all the categories of the variables included in Table 1). Companies included in the scope of application of Law 11/2018 are capital companies with at least an average number of 500 employees that are public interest entities, or large companies according to the limits establishes by Directive 2013/34. As they are large-sized companies, all of them show all their information on their website. Publishing of their non-financial information was done voluntarily in 2017, except certain aspects related to their corporate governance required compulsorily by the capital market supervisor. In 2018, the disclosure of this information according to Law 11/2018 was compulsorily required.

Law 11/2018 establishes that non-financial information must be included in the management report as a nonfinancial information statement. But it is also allowed to include it in an independent report if it is specified in the management report. This separate report may have different names, such as sustainability report. In these cases, in which the non-financial information was not included in the management report, we looked for it and it has allowed us to add as a new variable in the database the name of the report that includes the non-financial information. According to Law 11/2018, the name should be non-financial information statement in the management report but the possibility to publish an independent and separated report gives the flexibility to find the non-financial information under other names.

All the data has been analyzed using SPSS to obtain its main statistics segmented by year. To check if there are significant relationships between pair of variables, we have run contingency tables and chi-square statistics. To accept as statistically significant, we have assumed a confidence interval of $95 \%$ for these relationships

\subsection{Sample description}

Firstly, we compile the information of those companies that have audited their financial information. We can point out that they are mainly audited by the Big Four. This study shows that $32.9 \%$ of companies were audited by $\mathrm{PwC}, 30.1 \%$ by Deloitte, $15.1 \%$ by EY and $17.8 \%$ by KPMG. Another variable related to the auditing report is the opinion of the auditor. All companies have had a positive review in the two years analyzed (2017 and 2018).

When speaking about external assurance, it is also mainly provided by the Big Four. In 2017, when Law 11/2018 was not published, 16 companies did not contract assurance, and in 2018 it was only one company that did not. In some cases, the assurance in 2017 was referred to as social responsibility instead of non-financial information as in 2018. 30.1\% of assurance was provided by PwC, the leader in assurance as in auditing. The other Big Four provided a similar number of assurances, about $12 \%-15 \%$.

In the variable scope of the non-financial information the topics mentioned in the two years are included. Law $11 / 2018$ says that a non-financial information statement must include significant information. This is referred to environmental aspects, social matters, employees' questions, human rights, or fight against corruption or bribery, and finally information about society (Law 11/2018, First article). If companies mention all these topics the scope will be exhaustive. Although in 2017 the length of the report of analyzed companies was smaller than in 2018, companies have included all the topics in both years, which allows to have an exhaustive report.

All the companies in the two analyzed years have followed GRI standards in order to elaborate their nonfinancial information, with only one exception: a company that did not say what the followed standards were in 2017 (Table 2). These GRI standards can also be applied to different scopes (Figure 1). The core scope is to follow GRI standards including only essential information about all the topics. The exhaustive scope is the most detailed information in each one of the topics. $72.6 \%$ of the companies used the core scope and only $21.9 \%$ the exhaustive scope being mostly banking companies. 


\begin{tabular}{|lr|}
\cline { 2 - 2 } \multicolumn{1}{c|}{} & \multicolumn{2}{c|}{$\mathbf{\%}$} \\
\hline Other & 1.4 \\
\hline GRI & 98.6 \\
\hline Total & $\mathbf{1 0 0 . 0}$ \\
\hline
\end{tabular}

Table 2. Standards used in non-financial information

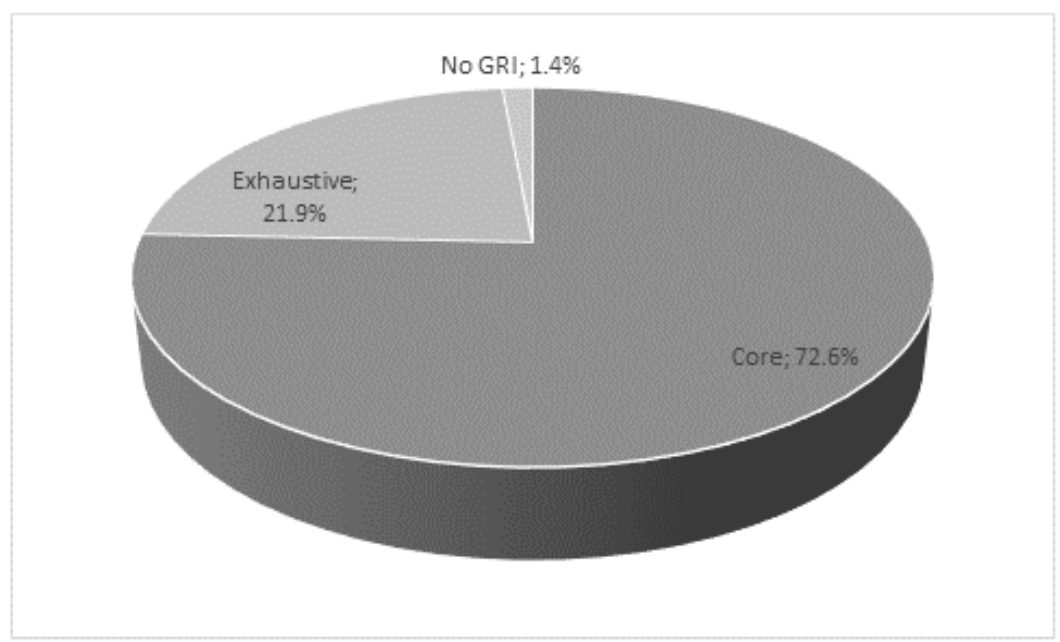

Figure 1. Scope of application of GRI standards in the sample

The variable web shows if it is easy to find the reports. $79.5 \%$ of the companies have got a website with easy access to the different reports in those two years. The other companies do not have such an easy access because:

- the company obliges to download the report,

- the non-financial information is separated from shareholders when is included in the annual accounts,

- the company does not publish all the reports in an organized way.

Non-financial information was included in $67.1 \%$ of the management reports, so the majority of the companies comply with the required by Law 11/2018. 19.2\% of the companies included it out of the annual accounts and they mentioned its location in the management report but only one company did not make reference to this location. Seven companies included non-financial information as an annex, of the annual accounts, or the management report, and so they would comply with Law 11/2018. This information is shown on Figure 2.

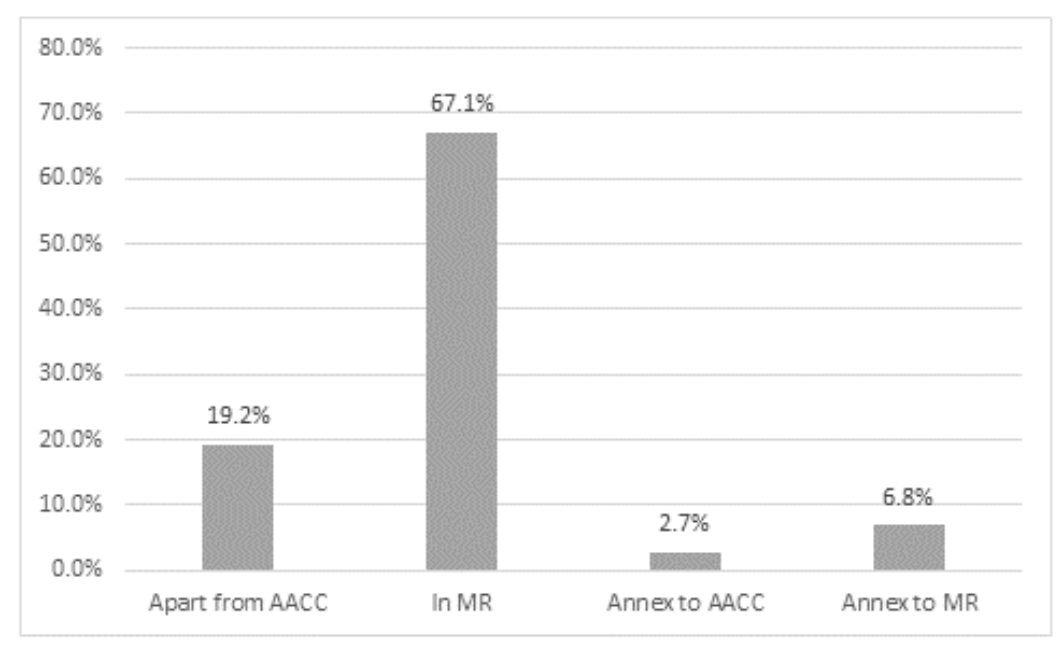

Figure 2. Location of non-financial information in the sample 
Variable defined as location tells us where non-financial information is included in shareholders link of their website in the two analyzed years (location of non-financial information is shown on Figure 3). In the majority of the companies, $60.3 \%$, of this information was included in the annual accounts, $15.1 \%$ in the annual report, $19.2 \%$ included non-financial information apart from annual accounts, in the CSR section, in the management report, or the non-financial information statement in the shareholders section on the website.

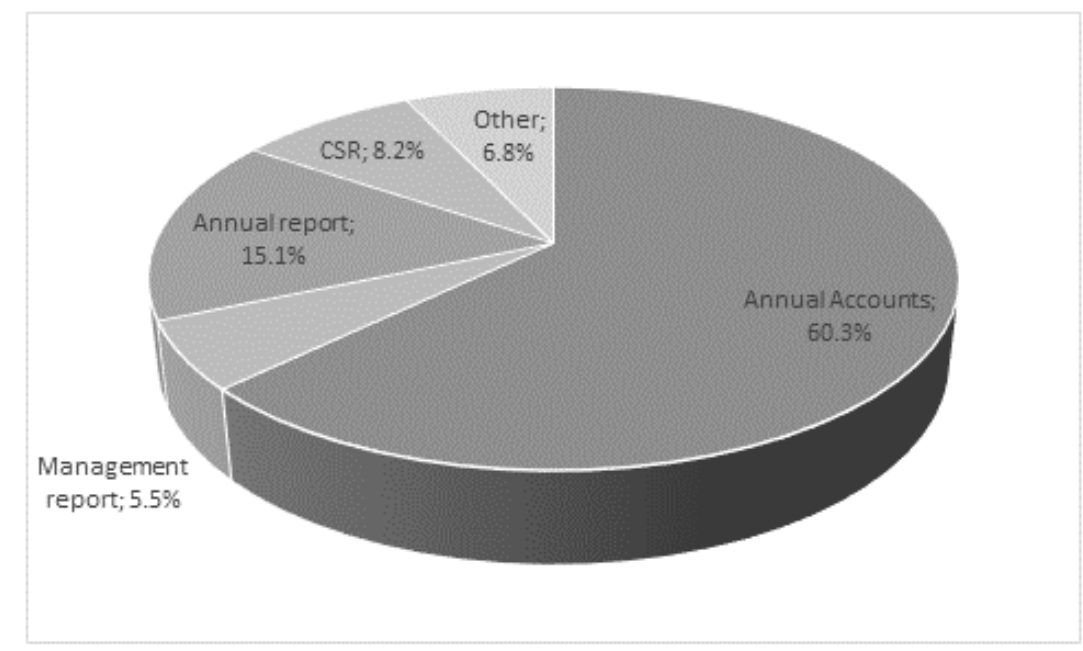

Figure 3. Location of non-financial information in the sample

There was also checked if non-financial information was included in the website but not in the share-holders' section. Only $37 \%$ of the companies do not have a specific section on their website, which means that they included their non-financial information in their annual accounts. $34.2 \%$ of the other companies included their non-financial information in a specific section about sustainability and the others in a specific section about CSR.

The next studied variable is the name given to non-financial information when it was not included in the management report. $27.5 \%$ of the companies called it CSR report, $20.5 \%$ non-financial information, and $17.8 \%$ sustainability report. The other companies did not have another name because it is included in the annual accounts.

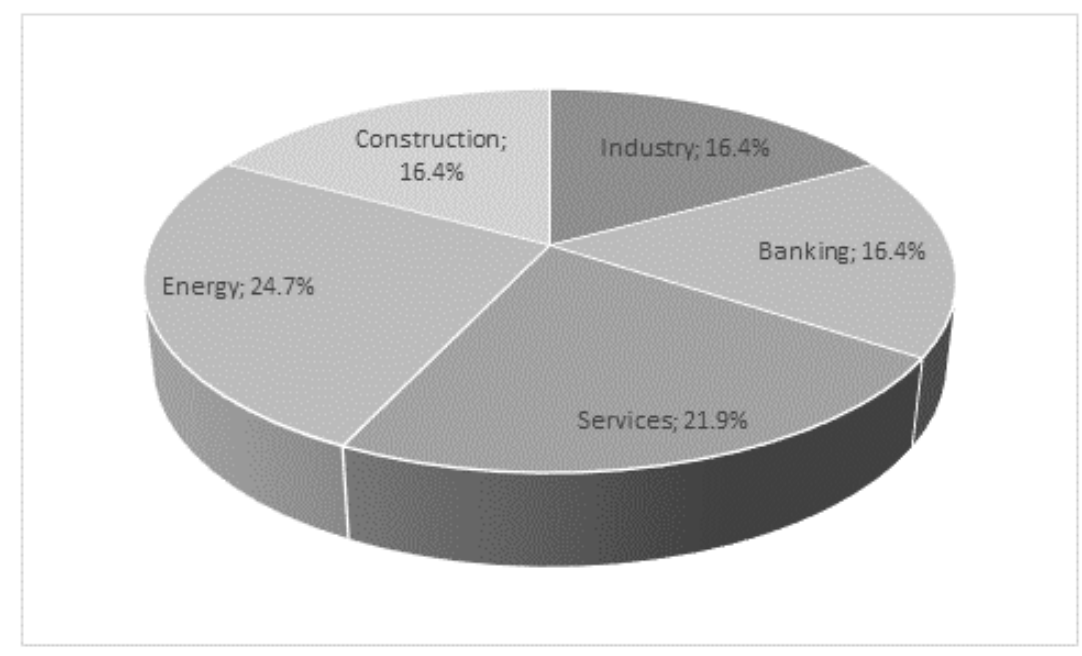

Figure 4. Sectors of companies in the sample

Companies listed on the Spanish Ibex 35 operate in different sectors that have been grouped into five types: banking, energy, construction, services, and industry (Figure 4). The banking sector includes financial entities and banks in the sample. The energy sector is composed of renewable energy companies and gas. Construction is 
composed of real states, construction companies, and hotel holdings. Services include insurances, advisors, telecommunication companies, and airport companies. Industry includes those companies operating in steel manufacturing, iron and steel industry, automotive, textile, manufacture of plastic containers, and pharmaceutical.

\section{Results}

\subsection{Disclosure and assurance of non-financial information. Comparison between the last year of voluntary report and the first year of compulsory report}

In this first part of the results, were 2018 and 2017 are going to compare for disclosure of non-financial information and its assurance. Due to the application of Law 11/2018, the companies are obliged to disclose non-financial information, or include it in the management report as a non-financial statement or as a separate report specifying in the management report where it is disclosed. The auditor only has to check if this information is included or mentioned in the management report.

In this section, we have segmented the sample depending on the year in order to check the differences between the last year of voluntarily reporting and assurance of non-financial information and the first year of application of its compulsory.

In year 2017 the main auditing companies of the companies listed on Ibex 35 were Deloitte $(37 \%)$ and PWC (31\%). In 2018, Deloitte reduced the number of audits (26\%) and PWC was the leader in auditing financial information (37\%), followed by KPMG and EY (it is shown in Table 3). It means that regardless of the changes in Law 11/2018, the Big Four are the companies that mainly audit and provide assurance of companies listed on Ibex 35, as it is concluded in previous studies (González \& Ortiz, 2017; Marín \& Ortiz, 2018; Ortiz \& Marín, 2014, 2016; Rubio \& Ortiz, 2019).

\begin{tabular}{|c|r|r|}
\cline { 2 - 3 } \multicolumn{1}{c|}{} & \multicolumn{2}{c|}{$\mathbf{\%}$} \\
\cline { 2 - 3 } \multicolumn{1}{c|}{} & $\mathbf{2 0 1 7}$ & \multicolumn{1}{c|}{$\mathbf{2 0 1 8}$} \\
\hline EY & 14.3 & 17.1 \\
\hline Deloitte & 37.1 & 25.7 \\
\hline KPMG & 17.1 & 20.0 \\
\hline PWC & 31.4 & 37.1 \\
\hline Total & $\mathbf{1 0 0 . 0}$ & $\mathbf{1 0 0 . 0}$ \\
\hline
\end{tabular}

Table 3. Auditing companies in the sample segmented by year

Changes in the Big Four can be related to the fact that in 2018 assurance was compulsorily required, and this can be done by the auditing company of the financial information. When analyzing the companies that had provided assurance, the ranking of the companies is different from the one obtained from the auditing of financial information (this information is shown in Table 4). In 2017, when assurance was voluntary, 42\% of the companies did not contract it. The other $58 \%$ is mainly shared by PWC (31\%) and Deloitte (11\%). After the publishing of Law 11/2018, there was only one company that did not contract its assurance in 2018. In 2018, PWC is the leading company providing assurance (31\%), while the other companies increased the number of assurances provided, as it is the case of KPMG and EY, which have increased to $5.7 \%$ and $8.6 \%$ to $20 \%$. There was only one company that contracted its assurance with a company different from the Big Four. As we have previously checked, we have obtained that auditing and assurance by large listed companies is provided by the large specialized multinationals. 


\begin{tabular}{|c|r|r|}
\cline { 2 - 3 } \multicolumn{1}{c|}{} & \multicolumn{2}{c|}{$\mathbf{\%}$} \\
\cline { 2 - 3 } \multicolumn{1}{c|}{} & $\mathbf{2 0 1 7}$ & $\mathbf{2 0 1 8}$ \\
\hline There is no assurance & 42.9 & 2.9 \\
\hline EY & 5.7 & 20.0 \\
\hline Deloitte & 11.4 & 20.0 \\
\hline KPMG & 8.6 & 22.9 \\
\hline PWC & 31.4 & 31.4 \\
\hline Other & 0 & 2.9 \\
\hline Total & $\mathbf{1 0 0 . 0}$ & $\mathbf{1 0 0 . 0}$ \\
\hline
\end{tabular}

Table 4. External assurance providers in the sample segmented by year

Regarding the variables related to the scope of non-financial information, the standards used to elaborate it, and the opinion of the auditor have been the same during the two years analyzed. Companies follow GRI with an exhaustive scope, including all the non-financial information, and everyone with a positive opinion. There can be pointed out an increase in the scope of GRI application. Although the majority option is the core application of GRI (71.4\% in 2018), this percentage has increased in the exhaustive option from $17 \%$ in 2017 to $28.6 \%$ in 2018 . The results obtained for these variables are shown on Table 5 .

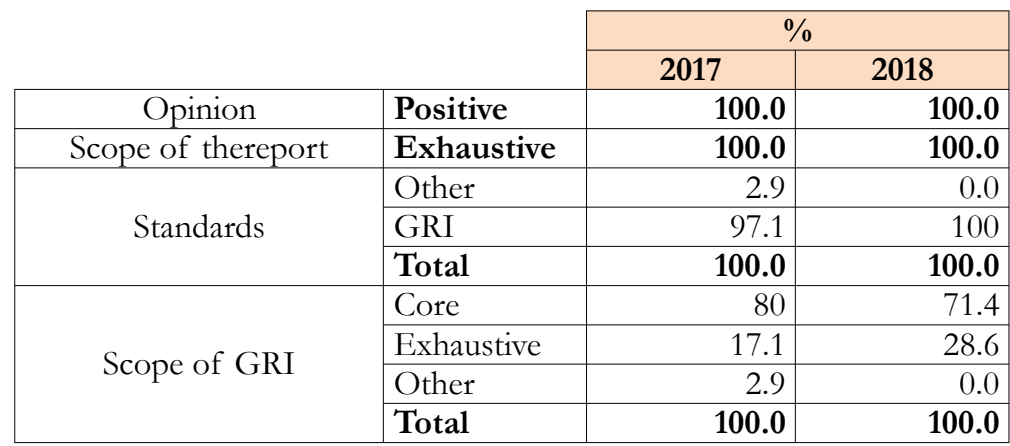

Table 5. Opinion of auditing report. Scope of the report, standard, scope of GRI of the non-financial information segmented by year

In $201774 \%$ of non-financial information was included in the management report and only $20 \%$ was out of it. In $2018,65.7 \%$ of the companies continued including non-financial information in the management report. This reduction was because there were two companies that included non-financial information as an annex to their annual account and other company as an annex to the management report (these results are shown in Table 6 regarding the location of non-financial information). It is clear that the main option to locate non-financial information is the management report, as it is required by Law 11/2018, and the main option is also voluntarily chosen before application of this Law. This is also the location advised by the PTF-NFRS of the EFRAG in its recently launched proposal about where to include non-financial information (EFRAG, 2021a).

\begin{tabular}{|c|r|r|}
\cline { 2 - 3 } \multicolumn{1}{c|}{} & \multicolumn{2}{c|}{$\mathbf{\%}$} \\
\cline { 2 - 3 } \multicolumn{1}{c|}{} & $\mathbf{2 0 1 7}$ & $\mathbf{2 0 1 8}$ \\
\hline Apartfrom AACC & 20.0 & 20.0 \\
\hline Included in MR & 74.3 & 65.7 \\
\hline Annex to AACC & 0.0 & 5.7 \\
\hline Annex to MR & 5.7 & 8.6 \\
\hline Total & $\mathbf{1 0 0 . 0}$ & $\mathbf{1 0 0 . 0}$ \\
\hline
\end{tabular}

Table 6. Location of non-financial information in the sample by year

With reference to the location of non-financial information in the two analyzed years, when crossing these two variables in a contingency table and run a chi-square test, we have obtained a significant relationship between the two variables (it is shown in Table 7). 
$74.3 \%$ of non-financial statements in 2017 were included in the management report, $20 \%$ included in nonfinancial information apart from annual accounts and only $5.7 \%$ added it as an annex to the management report. In 2018, 65.7\% non-financial information was included in the management report, apart from annual accounts $20 \%, 8.6 \%$ an annex to the management report and $5.7 \%$ an annex to the annual accounts. So, we can highlight that before the Law 11/2018 companies were locating non-financial information in the management report. After the application of this Law, some companies prefer separating non-financial information from management report and including it as an annex to the annual accounts or the management report.

\begin{tabular}{|c|c|c|c|}
\hline & & 2017 & 2018 \\
\hline \multirow[t]{2}{*}{ Apart from AACC } & $\begin{array}{l}\% \text { in location of non-financial } \\
\text { information }\end{array}$ & $50.0 \%$ & $50.0 \%$ \\
\hline & $\%$ in year & $20.0 \%$ & $20.0 \%$ \\
\hline \multirow[t]{2}{*}{ In the MR } & $\begin{array}{l}\% \text { in location of non-financial } \\
\text { information }\end{array}$ & $53.1 \%$ & $46.9 \%$ \\
\hline & $\%$ in year & $74.3 \%$ & $65.7 \%$ \\
\hline \multirow[t]{2}{*}{ Annex to AACC } & $\begin{array}{l}\% \text { in location of non-financial } \\
\text { information }\end{array}$ & $0.0 \%$ & $100.0 \%$ \\
\hline & $\%$ in year & $0.0 \%$ & $5.7 \%$ \\
\hline \multirow[t]{2}{*}{ Annex to MR } & $\begin{array}{c}\% \text { in location of non-financial } \\
\text { information }\end{array}$ & $40.0 \%$ & $60.0 \%$ \\
\hline & $\%$ in year & $5.7 \%$ & $8.6 \%$ \\
\hline \multirow{3}{*}{ Total } & $\begin{array}{l}\% \text { in location of non-financial } \\
\text { information }\end{array}$ & $47.9 \%$ & $47.9 \%$ \\
\hline & $\%$ in year & $100.0 \%$ & $100.0 \%$ \\
\hline & $\%$ total & $47.9 \%$ & $47.9 \%$ \\
\hline
\end{tabular}

Table 7. Relationship between the location of non-financial information and year Note: $X^{2}(8)=75.486, P<0.001$

The presentation of non-financial information has evolved from one year to the other. In both years, $62.9 \%$ of the companies had such information contained in the consolidated annual accounts document appearing in the "Shareholders" section. While in 2017 some handed in the management report outside (8.6\%), in 2018 only 2.9\% of the companies did so. The same applies to corporate social responsibility, which in $201714.3 \%$ of companies chose this document to hand in non-financial information, and in 2018 only $2.9 \%$. The trend grows significantly in the reporting of the name annual report, $11.4 \%$ in 2017 compared to $20 \%$ in 2018 . The latter also occurs with the report as "Other", which increases from $2.9 \%$ in 2017 to $11.4 \%$ in 2018 . We can see these results on Table 8.

\begin{tabular}{|c|c|c|}
\hline & \multicolumn{2}{|c|}{$\%$} \\
\hline & 2017 & 2018 \\
\hline Annual Accounts & 62.9 & 62.9 \\
\hline Management report & 8.6 & 2.9 \\
\hline Annual report & 11.4 & 20.0 \\
\hline Coporate Social Responsibility & 14.3 & 2.9 \\
\hline Other & 2.9 & 11.4 \\
\hline Total & 100.0 & 100.0 \\
\hline
\end{tabular}

Table 8. Disclosure of non-financial information in the sample by year

When non-financial information was included out of the management report the most usual name was corporate social responsibility report $(42.9 \%)$ or sustainability report $(20 \%)$ in 2017 . While in 2018 these names are changed by non-financial information (42.9\%), as is shown in Table 9. The application of Law 11/2018 has increased the use of the words non-financial information, decreasing the use of CSR. There has also been a slight decrease in the use of the name of the sustainability report, although it seems that in the European discussion about this subject it is the most chosen option instead of non-financial information because the latter shows a negative connotation (EFRAG, 2021a). 


\begin{tabular}{|c|r|r|}
\cline { 2 - 3 } \multicolumn{1}{c|}{} & \multicolumn{2}{c|}{$\mathbf{\%}$} \\
\cline { 2 - 3 } \multicolumn{1}{c|}{} & $\mathbf{2 0 1 7}$ & \multicolumn{1}{c|}{$\mathbf{2 0 1 8}$} \\
\hline No name & 34.3 & 22.9 \\
\hline Non-financial information & 0.0 & 42.9 \\
\hline Sustainability report & 20.0 & 17.1 \\
\hline CSR & 42.9 & 14.3 \\
\hline Other & 2.9 & 2.9 \\
\hline Total & $\mathbf{1 0 0 . 0}$ & $\mathbf{1 0 0 . 0}$ \\
\hline
\end{tabular}

Table 9. Name of the report that includes the non-financial information when it is not included in the management report in the sample segmented by year

As previously mentioned, there are lots of companies that used to include their non-financial information in their annual accounts. However, everyone has got extra sections in their websites where to show their nonfinancial information. In 2017, 13 companies added this information to their corporate social responsibility section and 11 companies to their sustainability section. In 2018, 14 companies included it in the sustainability section and only 5 in the CSR section. These results can be seen on Table 10.

\begin{tabular}{|c|r|r|}
\cline { 2 - 3 } \multicolumn{1}{c|}{} & \multicolumn{2}{c|}{$\mathbf{\%}$} \\
\cline { 2 - 3 } \multicolumn{1}{c|}{} & $\mathbf{2 0 1 7}$ & $\mathbf{2 0 1 8}$ \\
\hline Only AACC & 31.4 & 45.7 \\
\hline Sustainability & 31.4 & 40.0 \\
\hline CSR & 37.1 & 14.3 \\
\hline Total & $\mathbf{1 0 0 . 0}$ & $\mathbf{1 0 0 . 0}$ \\
\hline
\end{tabular}

Table 10. Extra section to locate non-financial information in the sample by year

When speaking about the sector, it is not possible to segment the sample by year because sectors are the same each year.

Finally, the application of Law 11/2018 has not implied important changes in disclosure and assurance of nonfinancial information in Spain, because companies listed on Ibex 35 have to continue doing what they were doing previously voluntarily. So, this is the answer to our first research question.

\subsection{Relationships between auditor and assurance provider, voluntary vs obligatory of disclosure and assurance of non-financial information}

In this section, we analyze the possible relationship between auditing companies of financial information and assurance providers of non-financial information due to the fact the Law 11/2018 requires compulsorily disclosure and assurance of non-financial information.

Firstly, we have studied the relationship between auditors and assurance providers which is statistically significant with a degree of confidence of at least 95\% (this data is included in Table 11 and 12). These results are coherent with the ones obtained by other previous studies (González \& Ortiz, 2017; Marín \& Ortiz, 2018; Ortiz \& Marín, 2014, 2016; Rubio \& Ortiz, 2019) and our results of the previous section, because only with a few exceptions, we can say that there is a relationship between companies that audit and those that provide assurance, and they are usually the same company. We can highlight that PWC is the company that most assurances provide and it provides assurance not only to its audited companies.

Of those companies that have not done assurance, 25\% were audited by EY and 25\% by Deloitte, 18\% KPMG, and $31.3 \%$ PWC. From the total assurance that provided EY, 77,8\% were done to companies audited by EY and $22.2 \%$ to companies audited by KPMG. About assurance done by Deloitte, $81.8 \%$ were done to companies audited by Deloitte and 18,2\% to companies audited by PWC. Lastly, from the total of assurance provided by PWC, $66.5 \%$ were done to companies audited by itself, $18.2 \%$ to companies audited by Deloitte, and $9.1 \%$ to companies audited by KPMG. 


\begin{tabular}{|c|c|c|c|c|c|c|c|}
\hline & & \multicolumn{6}{|c|}{ Assurance provider } \\
\hline \multicolumn{2}{|r|}{ Auditor } & No assurance & EY & Deloitte & KPMG & PWC & Other \\
\hline \multirow{2}{*}{ EY } & $\%$ in auditor & $36.4 \%$ & $63.6 \%$ & $0.0 \%$ & $0.0 \%$ & $0.0 \%$ & $0.0 \%$ \\
\hline & $\%$ in assurance provider & $25.0 \%$ & $77.8 \%$ & $0.0 \%$ & $0.0 \%$ & $0.0 \%$ & $0.0 \%$ \\
\hline \multirow{2}{*}{ Deloitte } & $\%$ in auditor & $18.2 \%$ & $0.0 \%$ & $40.9 \%$ & $22.7 \%$ & $18.2 \%$ & $0.0 \%$ \\
\hline & $\%$ in assurance provider & $25.0 \%$ & $0.0 \%$ & $81.8 \%$ & $45.5 \%$ & $18.2 \%$ & $0.0 \%$ \\
\hline \multirow{2}{*}{ KPMG } & $\%$ in auditor & $23.1 \%$ & $15.4 \%$ & $0.0 \%$ & $38.5 \%$ & $15.4 \%$ & $7.7 \%$ \\
\hline & $\%$ in assurance provider & $18.8 \%$ & $22.2 \%$ & $0.0 \%$ & $45.5 \%$ & $9.1 \%$ & $100.0 \%$ \\
\hline \multirow{2}{*}{ PWC } & $\%$ in auditor & $20.8 \%$ & $0.0 \%$ & $8.3 \%$ & $4.2 \%$ & $66.7 \%$ & $0.0 \%$ \\
\hline & $\%$ in assurance provider & $31.3 \%$ & $0.0 \%$ & $18.2 \%$ & $9.1 \%$ & $72.7 \%$ & $0.0 \%$ \\
\hline \multirow{3}{*}{ Total } & $\%$ in auditor & $21.9 \%$ & $12.3 \%$ & $15.1 \%$ & $15.1 \%$ & $30.1 \%$ & $1.4 \%$ \\
\hline & $\%$ in assurance provider & $100.0 \%$ & $100.0 \%$ & $100.0 \%$ & $100.0 \%$ & $100.0 \%$ & $100.0 \%$ \\
\hline & $\%$ of total & $21.9 \%$ & $12.3 \%$ & $15.1 \%$ & $15.1 \%$ & $30.1 \%$ & $1.4 \%$ \\
\hline
\end{tabular}

Table 11. Relationship between assurance provider and auditor by year Note: $X^{2}(24)=147.056, P<0.001$

The next analyzed relationship tries to verify if companies keep their auditor in both years, or if the need to contract the compulsory assurance has also changed the auditor because both tasks can be done by the same provider. There is a statistically significant relationship between auditors in 2017 and 2018 as is shown in Table 12.

Auditings by EY are 45.5\% and 54.5\% respectively in 2017 and 2018. In the case of Deloitte, its auditings have been 59.1\% in 2017 and $40.9 \%$ in 2018. KPMG shows a breakdown in 2017 and 2018 of $46.2 \%$ and 53.8\%. Finally, PWC audits 45.8\% in 2017 and 54.2\% in 2018 (these results are included in Table 12). According to these results, we can say that auditing companies are maintaining their weight in the two years.

\begin{tabular}{|c|c|c|c|c|}
\hline & & 2017 & 2018 & Total \\
\hline \multirow{2}{*}{ EY } & $\%$ in auditor & $45.5 \%$ & $54.5 \%$ & $100.0 \%$ \\
\hline & $\%$ in year & $14.3 \%$ & $17.1 \%$ & $15.1 \%$ \\
\hline \multirow[b]{2}{*}{ Deloitte } & $\%$ in auditor & $59.1 \%$ & $40.9 \%$ & $100.0 \%$ \\
\hline & $\%$ in year & $37.1 \%$ & $25.7 \%$ & $30.1 \%$ \\
\hline \multirow{2}{*}{ KPMG } & $\%$ in auditor & $46.2 \%$ & $53.8 \%$ & $100.0 \%$ \\
\hline & $\%$ in year & $17.1 \%$ & $20.0 \%$ & $17.8 \%$ \\
\hline \multirow{2}{*}{ PWC } & $\%$ in auditor & $45.8 \%$ & $54.2 \%$ & $100.0 \%$ \\
\hline & $\%$ in year & $31.4 \%$ & $37.1 \%$ & $32.9 \%$ \\
\hline
\end{tabular}

Table 12. Relationship between auditing company and year Note: $X^{2}(8)=74.107, P<0.001$

Similarly, we have studied the relationship between assurance provider and year (2017 and 2018). In this case, we have also obtained statistically significant relationships with confidence over 95\% (Table 13).

From the total of assurance, 6.2\% was done in 2017 and $93.7 \%$ in 2018. These results show the effect of the first application of Law 11/2018 when the non-financial information is compulsorily required to be done by an external assurance. About total assurance provided by EY, 22.2\% was provided in 2017 and $77.8 \%$ in 2018 . Deloitte provided 36,4\% of its total in 2017 and $63.6 \%$ in 2018. KPMG also increased its assurance providing from $27.3 \%$ in 2017 to $72.7 \%$ in 2018 . PWC kept the percentage of assurance provided every year: $50 \%$ in 2017 and 50\% in 2018. Finally, there was only one company that contracted in 2018 its assurance with another company different from Big Four (Table 13).

So, we can point out the effect of the first application of Law 11/2018, since all assurance providers have increased in 2018 and only a small percentage was carried out in 2017, except PWC that keeps the same proportion during the two analyzed years. 


\begin{tabular}{|c|c|c|c|}
\hline & & 2017 & 2018 \\
\hline \multirow{2}{*}{ No assurance } & $\%$ in assurance provider & $93.8 \%$ & $6.3 \%$ \\
\hline & $\%$ in year & $42.9 \%$ & $2.9 \%$ \\
\hline \multirow{2}{*}{$\mathrm{EY}$} & $\%$ in assurance provider & $22.2 \%$ & $77.8 \%$ \\
\hline & $\%$ in year & $5.7 \%$ & $20.0 \%$ \\
\hline \multirow{2}{*}{ Deloitte } & $\%$ in assurance provider & $36.4 \%$ & $63.6 \%$ \\
\hline & $\%$ in year & $11.4 \%$ & $20.0 \%$ \\
\hline \multirow{2}{*}{ KPMG } & $\%$ in assurance provider & $27.3 \%$ & $72.7 \%$ \\
\hline & $\%$ in year & $8.6 \%$ & $22.9 \%$ \\
\hline \multirow{2}{*}{ PWC } & $\%$ in assurance provider & $50.0 \%$ & $50.0 \%$ \\
\hline & $\%$ in year & $31.4 \%$ & $31.4 \%$ \\
\hline \multirow{2}{*}{ Other } & $\%$ in assurance provider & $0.0 \%$ & $100.0 \%$ \\
\hline & $\%$ in year & $0.0 \%$ & $2.9 \%$ \\
\hline \multirow{3}{*}{ Total } & $\%$ in assurance provider & $47.9 \%$ & $47.9 \%$ \\
\hline & $\%$ in year & $100.0 \%$ & $100.0 \%$ \\
\hline & $\%$ of total & $47.9 \%$ & $47.9 \%$ \\
\hline
\end{tabular}

Table 13. Relationship between assurance provider and year Note: $X^{2}(12)=92.938, P<0.001$

There is another statistically significant relationship between auditor and sector (Table 14) with a degree of confidence over $95 \%$.

From the total of auditings in the banking sector, $58.3 \%$ are done by PWC, $16.7 \%$ by EY and KPMG and $8.3 \%$ by Deloitte. In the energy sector, there is a more proportionate distribution: $38.9 \%$ by EY, $33.3 \%$ by KPMG, $22.2 \%$ by PWC, and $5.6 \%$ by Deloitte. In the construction sector Deloitte $(58.3 \%)$ and PWC (41.7\%) are specialized. Deloitte audits the majority of services companies (56.3\%), and then KPMG (18.8\%) and PWC and EY $(12.5 \%)$. In the industry sector, EY did not do any auditing, while PWC did $50 \%$ of the sector, followed by Deloitte (33.3\%) and KPMG (16.7\%). So, we check that auditing companies are specialized by sectors in our sample: EY in energy with KPMG, Deloitte in construction and services companies and PWC is the leader auditing banking and the industry sector.

\begin{tabular}{|c|c|r|r|r|r|r|}
\cline { 3 - 7 } \multicolumn{2}{c|}{} & Banking & Energy & Construction & \multicolumn{1}{c|}{ Services } & \multicolumn{1}{c|}{ Industry } \\
\hline EY & $\%$ in sector & $16.7 \%$ & $38.9 \%$ & $0.0 \%$ & $12.5 \%$ & $0.0 \%$ \\
\hline Deloitte & $\%$ in sector & $8.3 \%$ & $5.6 \%$ & $58.3 \%$ & $56.3 \%$ & $33.3 \%$ \\
\hline KPMG & $\%$ in sector & $16.7 \%$ & $33.3 \%$ & $0.0 \%$ & $18.8 \%$ & $16.7 \%$ \\
\hline PWC & $\%$ in sector & $58.3 \%$ & $22.2 \%$ & $41.7 \%$ & $12.5 \%$ & $50.0 \%$ \\
\hline \multirow{2}{*}{ Total } & \% in sector & $\mathbf{1 0 0 . 0} \%$ & $\mathbf{1 0 0 . 0} \%$ & $\mathbf{1 0 0 . 0} \%$ & $\mathbf{1 0 0 . 0} \%$ & $\mathbf{1 0 0 . 0} \%$ \\
\cline { 2 - 7 } & $\mathbf{\%}$ of total & $\mathbf{1 6 . 4 \%}$ & $\mathbf{2 4 . 7 \%}$ & $\mathbf{1 6 . 4 \%}$ & $\mathbf{2 1 . 9 \%}$ & $\mathbf{1 6 . 4 \%}$ \\
\hline
\end{tabular}

Table 14. Relationship between auditor of financial information and sector Note: $X^{2}(20)=106.649, P<0.001$

\begin{tabular}{|c|c|r|r|r|r|r|}
\cline { 3 - 6 } \multicolumn{2}{c|}{} & Banking & Energy & Construction & \multicolumn{1}{c|}{ Services } & \multicolumn{1}{c|}{ Industry } \\
\hline No assurance & $\%$ in sector & $25.0 \%$ & $22.2 \%$ & $16.7 \%$ & $18.8 \%$ & $33.3 \%$ \\
\hline EY & $\%$ in sector & $8.3 \%$ & $38.9 \%$ & $0.0 \%$ & $6.3 \%$ & $0.0 \%$ \\
\hline Deloitte & $\%$ in sector & $0.0 \%$ & $11.1 \%$ & $16.7 \%$ & $31.3 \%$ & $16.7 \%$ \\
\hline KPMG & $\%$ in sector & $8.3 \%$ & $5.6 \%$ & $16.7 \%$ & $18.8 \%$ & $33.3 \%$ \\
\hline PWC & $\%$ in sector & $58.3 \%$ & $22.2 \%$ & $50.0 \%$ & $18.8 \%$ & $16.7 \%$ \\
\hline Other & $\%$ in sector & $0.0 \%$ & $0.0 \%$ & $0.0 \%$ & $6.3 \%$ & $0.0 \%$ \\
\hline \multirow{2}{*}{ Total } & \% in sector & $\mathbf{1 0 0 . 0 \%}$ & $\mathbf{1 0 0 . 0} \%$ & $\mathbf{1 0 0 . 0} \%$ & $\mathbf{1 0 0 . 0} \%$ & $\mathbf{1 0 0 . 0} \%$ \\
\cline { 2 - 7 } & \% of total & $\mathbf{1 6 . 4 \%}$ & $\mathbf{2 4 . 7} \%$ & $\mathbf{1 6 . 4} \%$ & $\mathbf{2 1 . 9} \%$ & $\mathbf{1 6 . 4 \%}$ \\
\hline
\end{tabular}

Table 15. Relationship between external assurance provider of non-financial information and sector Note: $X^{2}(30)=106.883, P<0.001$

Lastly, we obtain a statistically significant relationship between assurance providers of no-financial information and sector, as it is shown on Table 15 where results of chi-square with confidence over $95 \%$. are included. Some 
company in each sector did not contract external assurance. However, in 2017 assurance was not compulsorily required.

Assurance in each sector was provided by the same companies that audited financial information, only one company chose a different external assurance provider. As it happened with the auditing of financial information, $58.3 \%$ of assurance in banking were provided by PWC, then $8.3 \%$ by EY and KPMG, and finally Deloitte that did not provide anyone. In the energy sector, it is important the percentage of assurance provided by EY (38.9\%), followed by PWC (22.2\%), Deloitte (11.1\%), and KPMG (5.6\%). In the construction sector, the assurance was mainly provided by PWC (50\%), KPMG and Deloitte provided $16.7 \%$ each one in this sector and EY did not provide anyone.

In the services sector, the assurance provided by companies is more divided than in the other sectors. Deloitte is the biggest provider (31.3\%), followed by KPMG and PWC (18.8\%), EY and other assurance providers 6.3\%. In the industry sector assurance is mainly provided by KPMG (33.3\%), Deloitte, and PWC (16.7\%), and EY does not provide any assurance.

In conclusion, we can point out that assurance providers are specialized in the sector as the auditing companies. In the banking sector, there is a relationship with the assurance provider PWC, which has specialized in this sector and construction. EY has mainly specialized in assurance for companies operating in the energy sector, while Deloitte in services companies. And KPMG has specialized in the industry sector.

All the relationships previously proposed have been obtained as statistically significant, and so we can answer affirmatively to most of our research questions (research questions number 2, 5 and 6). Regarding the other research questions concerning auditing company or assurance provider change due to the compulsorily imposed by Law 11/2018, we can answer negatively, because we have not obtained evidence of significant changes (research questions number 3 and 4).

\section{Conclusions}

Although large companies are traditionally used to disclosing and voluntarily assuring non-financial information, it is compulsorily required in Spain by the Law 11/2018 from year 2018. Prior to this research work, it could seem that this change has implied changes in the companies' practices, but this change from voluntary to compulsory has not supposed important changes in them due to the flexibility allowed by Law 11/2018.

There have not been changes in large companies as regards auditing of financial information. They have kept their position of voluntarily providing elaboration and assurance of non-financial information and after Law 11/2018, as have been obtained from the study of data of 2017 and 2018 of companies listed on the Spanish Ibex 35. The main assurance providers are the Big Four, as it has been also checked in other previous studies (González \& Ortiz, 2017). Although in 2017 42\% of these 35 companies did not contract the external assurance of their non-financial information, one year later, in 2018, only one company did not contract its assurance. So, all the companies have increased their assurance. The first application of Law 11/2018 was not something new to these large listed companies, because they were used to doing voluntarily.

The standard framework used by $94,5 \%$ of the companies in the two years is the GRI standards (Global Reporting Initiative), although it is mainly applied in its core scope, over $70 \%$, applied less than $30 \%$ of the exhaustive scope.

About the location of non-financial information, more than $70 \%$ of the companies included it in their management report in the two studied years. So, the location required by Law 11/2018 was the one previously used in a voluntary way. When speaking about disclosure of non-financial information in their websites, $62.9 \%$ included it in the annual accounts, and $201820 \%$ in the annual report. If non-financial information was stated separated from the management report it was denominated as social responsibility report or sustainability report in 2017, however, in 2018 the companies mainly used the name non-financial information statement, as it is required in Law 11/2018. 
Auditing and assurance providers are both specialized in different groups of sectors when it is referred to companies listed on Ibex 35. EY is specialized in auditing and assurance providing to companies operating in the energy sector, PWC has focused mainly on the banking sector and some auditing to the industry sector, Deloitte works for the construction and services sector, and finally, KPMG audits companies in the energy sector and provides assurance to companies operating in the industry sector.

Nowadays we are witnessing a burning discussion about the future of non-financial information regulation in Europe, and so this study and its conclusions are current and essential because they are adding value to the proposal of Directive about this subject, within the Green Deal strategy. Similarly, proposals of the Project Task Force-Non-Financial Reporting Standards included in the EFRAG European Lab (EFRAG, 2021a) have been published the importance of external assurance, the need for alignment with all the other frameworks and standards generally accepted, as GRI standards, is highlighted or the fact that there are specificities and specializations by sectors, as we have obtained in this paper. Our conclusions are useful for regulators, issuers of non-financial information standards, assurance providers, elaborators, and professionals in this subject. These conclusions are also a starting point to understand the situation in Spain when waiting for all these possible future changes that can come from Europe in the non-financial information standardization.

The main limitation of this paper can be the sample size, even though it is representative of large listed Spanish companies. Besides, it is worth pointing out that there is a lack of comparable non-financial information because its disclosure has been traditionally voluntary, which has constrained the analysis to large companies and public interest entities, the ones compulsorily required. However, as future research lines, we are thinking about increasing the sample with listed companies from other European countries, similar to the Spanish case, or different from it, to continue studying in this field that has got a long way to walk.

\section{Declaration of Conflicting Interests}

The authors declared no potential conflicts of interest with respect to the research, authorship, and/or publication of this article.

\section{Funding}

The authors received no financial support for the research, authorship, and/or publication of this article.

\section{References}

Albareda, L. (2013). CSR Governance Innovation: Standard Competition-Collaboration Dynamic. Journal of Corporate Governance, 13(5), 551-568. https://doi.org/10.1108/CG-06-2013-0076

Berthelot, S., Coulmont, M., \& Serret, V. (2012). Do inverstors value sustainability reports?. Journal of Corporate Social Responsibility and Environmental Management, 19(6), 355-363. https://doi.org/10.1002/cst.285

Brammer, S., \& Pavelin, S. (2006). Voluntary Environmental Disclosures by Large UK Companies. Journal of Business Finance and Accounting, 33(7 and 8), 1168-1188. https://doi.org/10.1111/j.1468-5957.2006.00598.x

Crowther, D., \& Ortiz, E. (2013). Revelación de información de responsabilidad social en empresas internacionalizadas: Análisis comparado. Información Comercial Española, 873, 139-148.

EFRAG (2021a). Final Report. Proposals for a Relevant and Dynamic EU Sustainability Reporting Standard-Setting. Retrieved from: https://ec.europa.eu/info/sites/info/files/business economy euro/banking and finance/ documents/210308-report-efrag-sustainability-reporting-standard-setting en.pdf

EFRAG (2021b). Final Report on the ad personam mandate on Potential Need for Changes to the Governance and Funding of EFRAG. Retrieved from: https://ec.europa.eu/info/sites/info/files/business economy euro/banking and finance/documents/210308-reportefrag-governance-funding en.pdf

Goicoechea, E., Gómez-Bezones, F., \& Goitia-Berriozabal, L. (2020). Novedades y retos en materia de información no financiera y auditoría. Boletín de Estudios Económicos, LXXV(230), 321-350. 
González, M., \& Ortiz, E. (2017). Información no financiera y su verificación externa: GRI. Revista de Responsabilidad Social de la Empresa, 27, 85-106. Retrieved from: https://www.accioncontraelhambre.org/sites/default/files/documents/revista rse n27 3nov.pdf

Hernández, J. (2017). Pocas novedades en la transposición de la Directiva de Información no financiera. Blog KPMG Responsabilidad empresarial. Retrieved from: http://auditoria-auditores.com/articulos/articulo-auditoria-pocasnovedades-en-la-transposici-n-de-la-directiva-de-informaci-n-no-financiera//

IFRS (2021). IFRS Foundation Trustees announce working group to accelerate convergence in global sustainability reporting standards focused on enterprise value. Retrieved from: https://www.ifrs.org/news-and-events/news/2021/03/trusteesannounce-working-group/?utm source $=\mathrm{IFAC}+$ Main + List\&utm campaign $=34 \mathrm{cbca02f1-}$ SMP Survey Email to MBs 1132016 COPY 01\&utm medium=email\&utm term=0 cc08d67019-34cbca02f1-

Kilic, M., \& Kuzey, C. (2018). Determinants of forward looking disclosures in integrated reporting. Managerial Auditing Journal, 33(1), 115-144. https:// doi.org/10.1108/MAJ-12-2016-1498

KPMG. (2017). The KPMG Survey of Corporate Responsibility Reporting 2017. Retrieved from: https://home.kpmg/xx/ en/home/insights/2017/10/the-kpmg-survey-of-corporate-responsibility-reporting-2017.html

Laudal, T. (2011).Drivers and barriers of CSR and the size and internationalization of firms. Social Responsibility Journal, 7(2), 234-256. https://doi.org/10.1108/17471111111141512

Levy, D.L., Szejnwald Brown, H., \& De Jong, M. (2010). The Contested Politics of Corporate Governance. The case of the Global Reporting Initiative. Journal of Business and Society, 49(1),88-115.

https://doi.org/10.1177/0007650309345420

Law 11/2018, de 28 de diciembre. Por la que se modifica el Código de Comercio, el texto refundido de la Ley de Sociedades de Capital aprobado por el Real Decreto Legislativo 1/2010, de 2 de julio, y la Ley 22/2015, de 20 de julio, de Auditoría de Cuentas, en materia de información no financiera y diversidad. BOE Num.314. Sec.I, pag. 129833-129854. Retrieved from: https://www.boe.es/buscar/doc.php?id=BOE-A-2018-17989

Marín, L., \& Ortiz, E. (2018). Non-Financial information of Spanish companies and financial evolution. Social Responsibility Journal, 14(4), 782-801. https://doi.org/10.1108/SRJ-08-2017-0145

Ortiz, E., \& Marín, S. (2014). Global Reporting Initiative (GRI) as recognized guidelines for sustainability reporting by Spanish companies on the IBEX 35: Homogeneity in their framework and added value in the relationship with financial entities. Intangible Capital, 10(5),855-872. https://doi.org/10.3926/ic.492

Ortiz, E., \& Marín, S. (2016). Información no financiera y globalización empresarial. GCG Globalization, Competitiviness and Governability, 10(3), 16-36.

Ortiz, E., Marín, S., \& Santos, J.M. (2019). Guía de Elaboración del Estado de Información No Financiera. (Cuentas anuales individuales y cuentas anuales consolidadas). Registro de Economistas contables. Retrieved from: https://ec.economistas.es/wp-content/uploads/sites/5/2019/09/ECGuía-1-17.09.pdf

Ortiz, E., \& Fuster, M. (2019). Información integrada, verificación externa y otros condicionantes. Revista Innovar, 29(73), 39-54. https://doi.org/10.15446/innovar.v29n73.78010

Ortiz, E., Marín, S., \& Sánchez, L.A. (2020). Información integrada según el IIRC de 2011 a 2015. Revista de Administración de Empresas, 60(3), 222-234. https://doi.org/10.1590/s0034-759020200305

Rubio, S. \& Ortiz, E. (2019). Grandes firmas de auditoría y sus empresas auditadas: Sector, tamaño y honorarios de auditoría. Observatorio Contable, 7, 307-315.

World Business Council for Sustainable Development (wbcsd). (2016). Generating Value from External Assurance of Sustainability Reporting. Retrieved from: http://docs.wbcsd.org/2016/02/WBCSD Redefining assurance guide.pdf

Intangible Capital, 2021 (www.intangiblecapital.org)

Article's contents are provided on an Attribution-Non Commercial 4.0 Creative commons International License. Readers are allowed to copy, distribute and communicate article's contents, provided the author's and Intangible Capital's names are included. It must not be used for commercial purposes. To see the complete license contents, please visit https://creativecommons.org/licenses/by-nc/4.0/. 